\title{
AN ANALYSIS OF ENGLISH LANGUAGE TEACHING ACTIVITIES DURING COVID-19 PANDEMIC AT SMP PURNAMA JAKARTA
}

\author{
${ }^{1}$ Yulia Firza Safira, ${ }^{2}$ Muhamad Sofian Hadi, \& ${ }^{2}$ Zaitun \\ ${ }^{1}$ English Student, FIP, Muhammadiyah University of Jakarta, Indonesia \\ ${ }^{2}$ English Lecturer, FIP, Muhammadiyah University of Jakarta, Indonesia \\ Corresponding Author Email: zaitun.hateem@gmail.com
}

\begin{tabular}{ll}
\hline \hline Article Info & Abstract \\
\hline Article History & This study was led to know the activities of English teaching during the COVID- \\
Received: February 2021 & 19 pandemic at SMP Purnama Jakarta. This study utilized a qualitative \\
Revised: March 2021 & descriptive method, while the information assortment methods utilized interviews, \\
Published: April 2021 & observation, and documentation. Interviews were led with an English teacher \\
\hline Keywords & who teaches at SMP Purnama Jakarta, while polls were given to a few students \\
English teaching activities; $;$ & at SMP Purnama Jakarta. The subjects of this investigation were an English \\
Teaching techniques; & teacher and a few students at SMP Purnama Jakarta. The outcomes show that \\
Technology in ELT; & learning during the pandemic is way different from the regular learning (in- \\
& person) that was done before the COVID-19 pandemic. The distinction that can \\
& be seen is that the instructional framework, which was initially up in-person, \\
& turned out to be totally internet or technology-based by utilizing Google Meet, \\
& Google Classrooms, WhatsApp, YouTube, and other applications.
\end{tabular}

How to cite: Safira, Y. F., Hadi, M. S., \& Zaitun. (2021). An analysis of English language teaching activities during covid-19 pandemic at SMP Purnama Jakarta. JOLLT Journal of Languages and Language Teaching, 9(2), 212-219, DOI: https://doi.org/10.33394/jollt.v9i2.3528

\section{INTRODUCTION}

Humans use language as a tool to express their thoughts and feelings. It is in line with Martinez \& Castillo (2015) that stated language is only human subjects in however much they speak, say, and know. It is a coming thing from within the speaking subject that shows the significant deliberate motivation behind the individual speaker. With language, humans are able to understand each other. According to Ethnologue, also known as the world's languages, as cited in Stein-Smith (2017), there are 7,099 languages on the planet. However, there is a language that extremely broad spoken worldwide. It connects individuals from divergent nations, backgrounds, and languages. It is English. As reported by Rao (2015), English is the main language widely used in the world. It is also the most generally utilized language on global trade, diplomacy, mass entertainment, global media communications, and scientific publications. Those are the reasons to teach English. It isn't just essential but mandatory for foreign learners, including Indonesia. Thus, the researcher leads this study on how English teaching-learning activities at SMP Purnama Jakarta.

The World Health Organization (WHO) has concluded that COVID-19 has been assigned as a pandemic that happens all through the world (Zanke et al., 2020). WHO announced that the COVID-19 epidemic a public health emergency of international concern was. The COVID-19 outbreak spread external the city of Wuhan on January 30, 2020 (Shereen et al., 2020). At the end of 2019, Wuhan, a developing business center of China, experienced an outbreak of a novel COVID-19 that murdered over 1,800 and infected more than 70,000 people within the first fifty days of the pandemic. This outbreak then spread to all parts of the world. Presently, in excess of 105.000,000 individuals are influenced by the COVID-19 outbreak around the world. The COVID-19 pandemic outbreak has changed all parts of human existence on the planet, including Indonesia. In consonance with Caraka et al. 
(2020), COVID-19 has a serious and boundless effect, particularly in Indonesia. It was first revealed in Indonesia on March 03, 2020, quickly spread to each of the 34 provinces by April 09, 2020. From that point forward, COVID-19 has proclaimed a condition of the public debacle and well-being crisis. Currently, in excess of 1.110,000 individuals are influenced by COVID-19 in Indonesia.

World pioneers create exacting principles to foresee the spread of COVID-19. WHO prescribes a few normalized well-being conventions to envision the spread of COVID-19, for example, wearing masks, washing hands, not shaking other people's hands, and keeping up social and physical distancing. Feng et al. (in Suppawittaya et al., 2020) informed that everyone needs to follow the standard recommendation of prioritizing self-hygiene, including hand-washing whenever possible, using alcohol to clean substances that are touched, and using medical face-mask rationally when exposed to high-risk areas. It is in line with Lotfinejad et al. (2020) concerned about standard recommendations, especially hand hygiene. They stated hand hygiene with alcohol-based hand rub (ABHR) is commonly utilized around the globe as one of the best, simple and low-cost techniques against COVID-19 crosstransmission.

The COVID-19 pandemic outbreak has changed all parts of human existence. All life orders change immediately with this pandemic. Individuals are not permitted to leave their homes, go to work, neither go to schools in the name of social distancing. As stated in Pajarianto et al. (2020), the Republic of Indonesia's government, via the Ministry of Education and Culture and keep up by every local government, shifted student learning from schools to their homes through the Study from Home model. This is the right decision of the government since it supports the social distancing idea. In keeping with Aslam (2020), social distancing is a strategy to limit crowd interactions and prevent the spread of disease within groups of individuals. This is a typical practice that has been done overages to limit the spread of the virus by restricting its proliferation rate (R0) among communities.

Based on UNESCO's data as cited in Abidah et al. (2020) in Indonesia by Wednesday $(3 / 25 / 2020)$, as many as $68,265,787$ students were affected by the COVID-19. It brought about changes in teaching and learning interactions in schools. The problem is teachers and students are not permitted to do in-person learning. This disarray likewise affects teaching and learning activities at SMP Purnama Jakarta. In this way, the writer aims to expose the English teaching and learning process during the SMP Purnama Jakarta pandemic period.

\section{RESEARCH METHOD}

In this paper, researchers find out how the English language teaching during the COVID-19 pandemic works. This review also concerned the teaching techniques and media that teachers utilized during the outbreak.

\section{Research Design}

The method utilized in this exploration is the subjective study with the sort of phenomenological research. According to Qutoshi (2018), phenomenology as a way of thinking gives researchers a theoretical rule to comprehend phenomena at the degree of subjective reality. The writer utilized this technique since the writer needed to learn and dissect teachers' experience in teaching. Hence, with this study technique, the researcher could investigate the English teaching activity during the pandemic period.

\section{Research Subject}

The writer selected SMP Purnama Jakarta as the research object as it is located in the center of the city, and it has various backgrounds of the students. The subject in this study is an English teacher who teaches at SMP Purnama Jakarta. In this research, the writer discusses with one English teacher at SMP Purnama Jakarta. The teacher teaches two grades: grade 7 and 9 with a total of six classes compared to another English teacher in the school who only 
teaches one grade, which is grade 8 with few classes. The writer picked one exploration subject in light of the fact that the teacher is a key source who has met the necessities as a key witness. As indicated by Martha and Kresno (2016), there are four standards in deciding key witnesses. Those must be functioning members in the group, association, or culture being investigated, associated with the "recent" explored culture; have sufficient time, and convey data in their own language (normal).

\section{Instruments}

In this research, the instruments that the researcher used are interviews, observation, and documentation. The interview subject is the English teacher. The observation is conducted on seventh and ninth-grade students. Meanwhile, the documentation is taken by handwriting while interviewing the teacher and some pictures. Moreover, statements from respondents were also upheld and explained by a few students at SMP Purnama Jakarta. In this study, writers noticed fifty students at SMP Purnama Jakarta.

\section{Data Analysis}

The model that was utilized in analyzing the data on this study is qualitative method phenomenological research. First, the researcher organized all the data or a comprehensive picture of the English teaching activities during the COVID-19 pandemic at SMP Purnama Jakarta that has been collected. Second, the researcher read the data as a whole and made side notes about the data that is considered important then did the data coding. Third, the researcher found and classified the meaning of the English teacher's statements by doing horizon listing, namely that each statement is initially treated to have the same value. Furthermore, statements that are irrelevant to the topic and questions or statements that are repetitive or overlapping are eliminated so that what remains is only horizons (the textural meaning and the constituent or compiler elements of the English teaching activities during the COVID-19 pandemic at SMP Purnama Jakarta that are not distorted).

Next, the statements were then collected into units of meaning and then a description of how the English teaching activities during the COVID-19 pandemic at SMP Purnama Jakarta occurred. Then, the researcher developed an overall description of the English teaching activities during the COVID-19 pandemic at SMP Purnama Jakarta to find its essence. Then developed a textural description (regarding the English teaching activities during the COVID19 pandemic at SMP Purnama Jakarta that occurs in the respondent) and a structural description (which explains how it occurs). Afterwards, the researcher then provided a narrative explanation of the essence of the English teaching activities during the COVID-19 pandemic at the SMP Purnama Jakarta understudy and got the meaning of the English teacher's experience of it. In the last one, the researcher made a report on the experiences of the English teacher. After that, the combinations of these images are written.

\section{RESEARCH FINDINGS AND DISCUSSION Research Findings}

The information is taken from the English teacher and fifty students at SMP Purnama Jakarta in the finding and discussion. The writer shows the outcomes of the information from interviews, observation, and documentation that have been dissected. The writer focuses on the information assortment of the English teaching activities in pandemic time at SMP Purnama Jakarta.

The following are a portion of the discoveries acquired by writer from interviews with English teachers at SMP Purnama Jakarta regarding English language teaching activities during the COVID-19 pandemic.

\section{Changes in English teaching and learning activities}


Learning during the COVID-19 pandemic has critical changes, particularly in the learning framework. Learning that at first occurred conventionally or in-person transformed into online learning. In light of the outcomes of interviews with respondents, the respondents gave the following assertions:

Table 1

Interview results

\begin{tabular}{lll}
\hline No & Theme/Question & EFL Teachers' Responses \\
1 & What are some drastic changes in English & T: “.. The learning framework has drastically changed. \\
teaching and learning activities before and & Before the pandemic, we studied conventionally in the \\
after the COVID-19 pandemic at SMP & classroom and met in person. If students do not understand a \\
Purnama Jakarta? & material, they can immediately ask questions, and we (the \\
& teachers) can immediately explain, but now it is not the \\
& case. Likewise, the exercises and quizzes, if previously \\
& students used paper and stationery now they use \\
& smartphones. It's just that our assessment is a little different. \\
& We still use offline reports..."
\end{tabular}

In light of the information above, the writer can sum up that the learning framework that is utilized by the English teacher at SMP Purnama Jakarta before and after the COVID-19 pandemic is not the same. Before the pandemic, the teacher utilized a conventional approach in teaching where the teaching and learning activities occur in the physical classroom, while after the pandemic, it becomes totally internet-based. The same thing goes along with the practice of exercises and quizzes, where it becomes online-based. The different thing is just on how the teacher assesses the students where they still utilize the conventional way to provide the report cards to the parents.

\section{The utilization of lecturing strategy in English teaching during the pandemic period}

In teaching English during the pandemic, the teacher utilized some techniques. One of them is the lecturing strategy. The teacher gives an explanation of the learning material to students utilizing the video conference feature on Google Meet. Given the outcomes of interviews with respondents, the respondents gave the accompanying assertions:

Table 2

EFL Teachers' Response

\begin{tabular}{lll}
\hline No & Theme/Question & EFL Teacher's Response \\
1 & What kind of media and teaching strategy & T: “...I use textbooks as usual to explain the material I \\
& $\begin{array}{l}\text { that you use during the COVID-19 } \\
\text { pandemic? }\end{array}$ & discuss. It's just that I did it through Google Meet media..." \\
\end{tabular}

In light of the information over, the teacher utilized the lecturing technique in teaching English. The teacher does the lecturing technique by explaining the material via Google Meet. Via google meet is used to deliver their teaching materials. This media provides teachers with many features to learn virtually. Students and teachers can interact with each other.

\section{The utilization of task-based learning technique in English teaching in pandemic period}

Other than utilizing the lecturing technique. Teachers additionally use task-based learning strategies in getting the hang of during the COVID-19 pandemic. The task based learning technique is completed after the teacher gives an explanation of the material, teacher gives assignments in a two ways. Either sent by Google Classroom or Google Meet itself. Coming up next is the teacher's assertion regarding to the learning strategy: 
Table 3

EFL Teachers Responses

\begin{tabular}{|c|c|c|}
\hline No & Theme/Question & EFL Teacher's Response \\
\hline 1 & $\begin{array}{l}\text { Is there any other teaching strategy that } \\
\text { you use during the COVID-19 pandemic } \\
\text { and how do you do that? }\end{array}$ & $\begin{array}{l}\text { T: "...I give assignments to students. I give them in two } \\
\text { ways. The first (way) I send via Google Classroom and the } \\
\text { second (way) I give it directly during Google Meet..." }\end{array}$ \\
\hline 2 & $\begin{array}{l}\text { How about the collection of those } \\
\text { assignments? }\end{array}$ & $\begin{array}{l}\text { T: "...The collection of assignments is carried out in two } \\
\text { ways. The first way is to fill in or answer directly on Google } \\
\text { Classroom and the second way (students' assignment book) } \\
\text { to be photographed and then immediately send it to me } \\
\text { personally on WhatsApp..." }\end{array}$ \\
\hline
\end{tabular}

In light of the information above, the tasks giving and collection are carried out in two ways. First, on Google Classroom or Google Meet and second, on WhatsApp.”

\section{Discussion}

Teaching and learning activities during the COVID-19 pandemic changed radically, including the strategies and media utilized by teachers when teaching. Learning that at first occurred offline (in-person) turned out to be totally internet-based. Teaching and learning activities during the COVID-19 pandemic have carried a few changes to students, teachers, and even guardians. This assertion is in accordance with the assessment of Duraku and Hoxha (2020), who said that the COVID-19 has affected the education, well-being, and functioning of all parties involved and benefiting from educational systems in the world.

The teacher said that he generally offers help and inspiration to students so they don't feel exhausted when contemplating comfortable during this COVID-19 pandemic. The presence of high inspiration by the teacher can likewise build learning inspiration for students. This assertion is in accordance with the assessment of Hooda (2018), who said that a teacher who is enthusiastic about students learning and the content would find themselves motivated to go well beyond the minimum in developing activities that benefit students' learning. An enthusiastic teacher can make a tremendous difference in student motivation and engagement in regard to learning. This also goes along with the statement of Yolanda and Hadi (2019) that stated the teacher has the responsibility to guide students besides also giving students support and motivation so that they can improve their English skills.

The teacher expressed that teaching activities in the pandemic period had an adjustment in administration as a syllabus and lesson plans. The teacher presents the schedule as a framework of the fundamental material or abilities that students should master inside a specific timeframe. The syllabus depends on government guidelines and is controlled by the Ministry of Education and Culture. It goes straight with the assessment of Richards (as cited in Sabbah 2018) states that a syllabus is a specification of the content of a course of instruction that lists what will be taught and tested. The educational plan highlights incorporate topic, etymological goals, sequencing, and material to address the issues of specific students in specific settings. The teacher just uses a portion of the fundamental abilities in the schedule in teaching-learning activities during the COVID-19 pandemic, so not all material is instructed because it is beyond the realm of imagination if all the material is instructed in internet learning.

In the pandemic period, teachers utilized two sorts of teaching techniques, lecturing and task-based learning strategy. Lecturing strategy is done by the teacher by giving explanations through Google Meet. The meaning of the lecturing technique is in accordance with the 
assessment of Sutherland (1976), who stated that the lecturing method or technique is defined as a continuing oral presentation by the professor (or teacher); it is presumably a synthesis of his own reading, research, and experiences, interpreted in light of his own insights.

Moreover, teachers additionally use task-based learning strategies. Offering tasks to students is the primary focal point of learning that the teacher will utilize as proof of participation and appraisal. The teacher's utilization of task-based learning strategies is in accordance with Jeon and Hahn's assessment (as cited in Murat 2011). He contends that taskbased language learning or teaching (TBLT) has become a significant topic in the field of second language acquisition in terms of fostering process-focused syllabi and devising communicative tasks to enhance learners' real language use via the emergence of the communicative language teaching approach.

The respondent said that internet or informal learning strategies urge students to be autonomous in learning. This assertion is in accordance with the assessment of Stickler and Emke (as cited in Wang and Cheng 2019) that informal learning is a germane to the rise of lifelong learning, where learners are depicted as autonomous, social agents who actively seek learning tools, resources, and opportunities available in their surrounding environment (Kalaja et al. 2011). Autonomous learning should be possible by perusing the material, dissecting the material, and recordings given by the teacher. This can make students familiar with gathering and overseeing data acquired identified with learning material.

The utilization of teaching media during the COVID-19 pandemic is identified with the utilization of information and communication technology (ICT). Teachers and students at SMP Purnama Jakarta use mobile phones for teaching and learning activities during the COVID-19 pandemic. The utilization of mobile phones is in accordance with the assertion from Basak, Wotto \& Belanger (2018), who contends that mobile learning is complementary of both traditional understandings as well as e-learning.

The teacher utilized the teacher to help English teaching and learning activities during the pandemic incorporate utilizing the Google Meet, Google Classroom, WhatsApp, YouTube, and other applications. The utilization of these media is relied upon to make learning more pleasant. This assertion is in accordance with the assessment of Paechter \& Maier (2010), which say that students appreciated online learning for its potential in providing a clear and coherent structure of the learning material, in supporting self-regulated learning, and in distributing information.

During the pandemic at SMP Purnama Jakarta, the teaching and learning activities happened in-person and transformed into virtual ones. In teaching and learning activities during the COVID-19 pandemic, teachers solely use the internet-based learning technique. Internet-based learning is a learning process that utilizes the internet and digital media. When teaching during the pandemic, the media utilized by teachers are the utilization of some applications, for example, Google Meet, Google Classroom, WhatsApp, and YouTube.

\section{CONCLUSION}

In this part, the writer needs to create a conclusion from the outcomes of the study that have been done. English teaching and learning activities during the COVID-19 pandemic have a few changes. The changes are in the learning framework, which at first regularly ran (in-person) to internet-based learning. So that learning administration should likewise be changed to be totally on the internet, for instance, learning materials utilizing audio, video, YouTube, and Google Classroom.

The technique utilized by the teacher when teaching English during the COVID-19 pandemic were utilizing lecturing strategy and task-based learning strategy. The teacher completes the lecturing strategy by giving an explanation from the textbook material through Google Meet. The teacher additionally utilized a task-based learning strategy. The teacher 
gave a few tasks to the students through Google Classroom or Google Meet, then students do the assignments and submit them to Google Classroom or WhatsApp. The lessons have two capacities, for assessment and attendance.

The media utilized by the teacher in teaching and learning activities during the COVID19 pandemic is by utilizing the Google Meet, Google Classroom, WhatsApp, YouTube, and other applications. The teacher gives material as audio, picture, and video to students. Moreover, the teacher likewise utilizes YouTube as a learning medium to don't feel tired and be keener on learning materials. Different media utilized by the teacher is the utilization of Google Classroom to give daily test questions, midterm tests, and last semester tests.

\section{REFERENCES}

Abidah, A., Hidaayatullaah, H. N., Simamora, R. M., Fehabutar, D., \& Mutakinati, L. (2020). The impact of COVID-19 to Indonesian education and its relation to the philosophy of "Merdeka Belajar". Studies in Philosophy of Science and Education (SiPoSE) , 1 (1), $38-49$.

Aslam, F. (2020). COVID-19 and importance of social distancing.

Basak, S. K., Wotto, M., \& Bélanger, P. (2018). E-learning, M-learning, and D-learning: Conceptual definition and comparative analysis. E-Learning and Digital Media , 15, 191-216.

Caraka, R. E., Lee, Y., Kurniawan, R., Herliansyah, R., Gio, P. U., Kaban, P. A., et al. (2020). Impact of COVID-19 large scale restriction on environment and economy in Indonesia. Global Journal of Environmental Science and Management (GJESM) , 6, 65-84.

Duraku, Z. H., \& Hoxha, L. (2020). The impact of COVID-19 on education and on the wellbeing of teachers, parents, and students: Challenges related to remote (online) learning and opportunities for advancing the quality of education. 1-28.

Hismanoglu, M., \& Hismanoglu, S. (2011). Task-based language teaching: What every EFL teacher should do. Procedia - Social and Behavioral Sciences , 15, 46-52.

Lotfinejad, N., Peters, A., \& Pittet, D. (2020). Hand hygiene and the novel coronavirus pandemic: The role of healthcare workers. Journal of Hospital Infection , 105, 776-777.

Martha, E., \& Kresno, S. (2016). Metodologi penelitian kualitatif untuk bidang kesehatan. Jakarta: Rajawali Express.

Martinez, J., \& Castillo, J. G. (2015). The speech act as an act of knowing. International Journal of Language and Linguistics , 3 (6-1), 31-38.

Paechter, M., \& Maier, B. (2010). Online or face-to-face? Students' experiences and preferences in e-learning. Internet and Higher Education, 13, 292-297.

Pajarianto, H., Kadir, A., Galugu, N., Sari, P., \& Februanti, S. (2020). Study from home in the middle of the COVID-19 pandemic: Analysis of religiosity, teacher, and parents support againts academic stress. Talent Development \& Excellence, 12 (2s), 1791-1807.

Rao, P. S. (2019). The role of English as a global language. Research Journal Of English (RJOE) , 4 (1), 65-79.

Sabbah, S. S. (2018). English language syllabuses: Definition, types, design, and selection. Arab World English Journal , 9 (2), 127-142. 
Shereen, M. A., Khan, S., Kazmi, A., Bashir, N., \& Siddique, R. (2020). COVID-19 infection: Origin, transmission, and characteristics of human coronaviruses. Journal of Advanced Research , 24, 91-98.

Stein-Smith, K. (2017). Foreign languages: A world of possibilities. International Journal of Language and Linguistics , 4 (4), 1-10.

Suppawittaya, P., Yiemphat, P., \& Yasri, P. (2020). effects of social distancing, selfquarantine, and self-isolation during the COVID-19 pandemic on people's well-being, and how to cope with it. International Journal of Science and Healthcare Research , 5 (2), 12-20.

Sutherland, T. M. (1976). The lecture method. 29-33.

Wang, H.-c., \& Chen, C. W.-y. (2019). Learning English from YouTubers: English L2 learners' self-regulated language learning on YouTube. Innovation in Language Learning and Teaching .

Yolanda, D., \& Hadi, M. S. (2019). Using puppet games in teaching speaking for tenth graders of senior high school. English Language in Focus , 2 (1), 1-8.

Zanke, A. A., Thenge, R. R., \& Adhao, V. S. (2020). COVID-19: A pandemic declare by world health organization. IP International Journal of Comprehensive and Advanced Pharmacology, 5, 49-57. 